\title{
Understanding the effects of BIM implementation in corporation finance: An empirical study in China
}

DOI 10.2478/otmcj-2021-0028

Received: July 05, 2020; Accepted: March 10, 2021

\begin{abstract}
Building Information Modeling (BIM) has been acknowledged for promoting effectiveness and efficiency in project planning and management activities including design, bidding, and construction. Yet limited effort has been made to investigate the impacts of BIM implementation on corporate performance. Using the financial information of 314 Architecture, Engineering, and Construction (AEC) companies listed in the A-share market of China, this paper examines the economic benefits of BIM practice and assesses the influential mechanism of BIM implementation at the corporation level. The results reveal that BIM adoption contributes to better corporate profitability, especially in non-stateowned enterprises (non-SOEs). The positive impact of BIM implementation on profitability is achieved by the functions of promoting schedule efficiency and operation cost reduction. However, high initial BIM investment is still required in China's AEC companies at the current stage, and the effectiveness enhancement in corporation management has not been realized. By providing clear empirical evidence of the economic benefits of BIM adoption from a corporation perspective, this study might help improve top managers' awareness, intention, or support of future BIM utilization in China's AEC companies.
\end{abstract}

Keywords: corporation performance, BIM, efficiency improvement, cost reduction

\footnotetext{
*Corresponding author: Jianjun Ma, Department: Southern Marine Science and Engineering Guangdong Laboratory (Zhuhai); Guangdong Key Laboratory of Oceanic Civil Engineering; Guangdong Research Center for Underground Space Exploitation Technology; School of Civil Engineering, Sun Yat-Sen University, Guangzhou, PRC.E-mail:majianjun@mail.sysu.edu.cn

Zhimin Wang, Department: Research Center for Accounting and Economic Development of Guangdong-Hong Kong-Macao Greater Bay Area, School of Accounting, Guangdong University of Foreign Studies, Guangzhou, PRC
}

\section{Introduction}

Building Information Modeling (BIM) comprises a set of technologies and solutions aiming to enhance multiparty collaboration among owners, designers, contractors, and management teams to visualize and facilitate construction work in the Architecture, Engineering, and Construction (AEC) industries (Ghaffarianhoseini et al. 2017, Azhar et al. 2012). With benefits in promoting efficiency and facilitating collaboration (Doumbouya et al. 2016), BIM has been widely adopted in construction projects around the world, including in the US, UK, and in many countries in Europe (Jones and Bernstein 2012). Asian counties such as Singapore, Korea, Japan, and China have also reported BIM utilization, but the adoption percentage is lower (Cheng and $\mathrm{Lu}$ 2015). Owning the largest number of construction projects, China issued an official guideline in 2015 to promote BIM adoption and aimed for an adoption rate of $90 \%$ by the year of 2020 (Mohurd 2015). Yet, this aim appears to be behind schedule since $<20 \%$ of Chinese AEC firms had reported BIM usage by 2016 (Herr and Fischer 2019, Bui et al. 2016).

The goals of BIM implementation are to reduce costs, improve task effectiveness, and facilitate communication (Won and Lee 2016), but the decisions of whether or not to utilize BIM are dependent on the speculated benefits (Barlish and Sullivan 2012). Despite the benefits and barriers of BIM adoption summarized in previous studies, researchers point out that the overall effectiveness of BIM usage and proper evaluation of BIM benefits have not been fully established (Barlish and Sullivan 2012, Ghaffarianhoseini et al. 2017). The vague definition of BIM benefits leads to the phenomenon of a high level of awareness but a low level of implementation of BIM in construction projects (Ghaffarianhoseini et al. 2017). More importantly, Won and Lee (2016) argued that from a life-cycle perception, BIM benefits should be reflected in corporate performance rather than project achievement. However, limited effort has been made to explore and analyze the impacts of BIM usage on corporate performance. 
Therefore, the following questions are raised: (1) Do BIM-adopted companies have better financial performance compared to those not adopted companies? (2) How does BIM adoption influence corporate performance? Using the financial information of AEC companies listed in China's A-share market, this study is among the first initiatives to provide an empirical analysis of BIM benefits from corporation performance perspectives. The findings of this study would provide clear BIM benefit measures as well as influential mechanisms in the perception of organization performance, which might improve top managers' awareness and willingness of BIM adoption in the AEC industries.

\section{Literature review}

BIM could be seen as a platform for multifunction technologies and solutions to construction project management. As a new technology in the construction industry, many studies have been devoted to analyze BIM from different perspectives. In this section, we first review the overall impact of new technologies on corporation performance. Then, the specified benefits and barriers of BIM adoption are summarized.

\subsection{Technology adoption and corporation performance}

Along with the development of technology, companies belonging to different industries have embraced new technologies to facilitate their operation. Most researchers agree that technology innovation and technology embeddedness would lead to better corporation performance (Liu and Wu 2011, Kim et al. 2011). For instance, studies find that information technology investment in the rail industry contributes to productivity improvements, including volume increase, operation expense reductions, and yield management (Cline and Guynes 2001). Moreover, in retail firms, technology investment could generate positive results in productivity growth (Doms et al. 2004). The development of Internet Technology (IT) has brought about significant changes in corporate operations and management. For instance, IT investment could upgrade IT infrastructure flexibility and IT technical skills, which further promotes firm performance through the effect of enhancing absorptive capacity and corporate entrepreneurship (Rehman et al. 2020). In addition, business processes reengineering could be realized with the help of information technology (Albadvi et al. 2007). These fundamental changes in corporate operation could enhance the effects of productivity and management efficiency (Hellegers et al. 2011). However, despite the benefits of reducing fixed overhead cost and improving profits, IT investment would also increase the total production costs and might harm firm performance (Thatcher and Oliver 2001). Thus, new technologies could have both positive and negative impacts on corporation performance, under different circumstances.

\subsection{Benefits of BIM implementation}

Known as an integrated platform which enables better collaboration among different stakeholders, BIM technology has brought about significant benefits to construction projects in various perspectives. The potential benefits associated with BIM implementation are a major motivation factor for BIM adoption (Hong et al. 2019). From a project management point of view, BIM enhances task effectiveness, improves project efficiency and productivity, and reduces rework during construction (Cao et al. 2015, Tan et al. 2019, Li et al. 2018, Olawumi and Chan 2019). BIM also improves multiparty communication and understanding among different participations and promotes efficiency in the processes of scheduling, design, construction, maintenance, and facility management (Jin et al. 2017, Lin and Yang 2018, Herr and Fischer 2019, Georgiadou Maria 2019). Realizing the above benefits, BIM helps improve the quality of design, construction, and the overall project quality (Chan et al. 2019). BIM is also appreciated for being environmentally sustainable, as it facilitates the selection of sustainable materials and components, together with reducing material wastage and projects' environmental impacts (Olawumi and Chan 2019).

From a financial perspective, BIM adopters have reported economic benefits related to cost reduction, cost control, and time savings throughout the project life cycle (Bryde et al. 2013, Chan et al. 2019). For instance, the BIM software could help contractors analyze both cash inflows and cash outflow patterns for equipment, manpower, and materials of a project and generate proper financial decisions ( $\mathrm{Lu}$ et al. 2016). In addition, the benefits of project effectiveness and efficiency achieved by BIM technology would help improve projects' financial performance by saving project costs (Herr and Fischer 2019, Tan et al. 2019, Lin and Yang 2018). Therefore, Walasek and Barszcz (2017) developed a bunch of indicators to calculate the 
return on investment (ROI) to measure these financial benefits of BIM implementation, including net revenue, cash flow, and costs of employee training, workstations, maintenance, and so on. However, Love et al. (2013) have argued that ROI did not accurately reflect the real cost and benefits of BIM and suggested that intangible benefits and indirect costs, such as improved productivity and potential revenue growth, associated with BIM should be taken into consideration. However, the measurement and empirical analysis of financial cost and benefits of BIM implementation from a corporate performance perspective is still inadequate.

\subsection{Barriers of BIM implementation}

Despite the benefits claimed by researchers and industry practitioners, the adoption of BIM is also hindered by various barriers. For instance, researchers have found that technical aspects such as slow technology development (Lindblad 2013), lack of software interoperability, and non-user-friendly format (Ghaffarianhoseini et al. 2017) are substantial reasons for not adopting BIM. Human resource issues such as lack of professional architects and engineers or expertise (Chan et al. 2019, Chien et al. 2014), lack of knowledge and experience (Khoshfetrat et al. 2020), as well as the time and cost required for human resource training (Lindblad 2013) are major risk factors that hinder BIM implementation. Although BIM facilitates and improves the communication and understanding among project participants, some construction stakeholders have shown resistance to embrace the technology (Chan et al. 2019). In addition, from the macro perspective, insufficient government lead or support, lack of standards (Zhou et al. 2019, Mehran 2016), or legislation (Aladag et al. 2016, Tan et al. 2019) are vital environmental factors that discourage BIM adoption.

More importantly, financial and managerial barriers are critical factors affecting the intentions and decisions of adopting BIM. Studies have demonstrated that top managers' awareness and support are key determinants of companies' intention to use BIM (Son et al. 2015). Especially, high initial cost and front-end investment (Aladag et al. 2016, Chan et al. 2019) combined with low ROI (Ghaffarianhoseini et al. 2017) as well as ignorance about the added value of BIM are the most significant factors affecting the motivation of BIM adoption. Thus, Georgiadou Maria (2019) found that small- and medium-sized enterprises had limited financial capability in investing in developing digital capabilities, although there was widespread awareness on BIM.

\subsection{Other influential factors of BIM adoption}

Apart from the benefits and barriers of BIM adoption, Barlish and Sullivan (2012) have pointed out that the success of BIM depended on many external factors, including size of the project, team members' BIM proficiency and communication with project teams, and other organizational factors. Liu et al. (2017) further proved that BIM collaboration was influenced by corporates' IT capacity, technology management, attitude and behavior, role-taking, trust, communication, leadership, learning, and experience, all of which could be categorized into three dimensions, namely, technology, people, and process. The existing staff's capability in using BIM tools positively affects the establishment of an organizational knowledge support system, which determines the decision of adopting BIM eventually (Hong et al. 2019). Therefore, the decisions and effects of BIM usage might link to an organization's features such as financial ability, experience, size, innovation needs, and innovation awareness (Singh and Holmström 2015, Gledson Barry and Greenwood 2017), which will be tested in this study.

\section{Data and methods}

\subsection{Data and samples}

Rapid urbanization and intense infrastructure construction in China have boosted the development of AEC industries. There are in total 319 AEC companies (including real-estate enterprises) listed in China's A-share market in 2019. After deleting five companies labeled as Special Treatment, with problems of financial crisis to avoid the impact of negative financial performance on our analysis, 314 enterprises are taken as the research sample for this study. The major reasons for choosing these A-share market listed companies as our research sample are as follows: (1) their mandatory release of annual financial reports provide information about BIM adoption and corporate performance; (2) massive public attention and pressure of being industry leaders stimulate their willingness to invest in and adopt new technologies; and (3) most of them are large enterprises with a stronger financial capability of BIM investment, since the high front-end investment required by BIM might inhibit those small and medium AEC enterprises from adopting the technology, as they might not have enough supporting funds. The features of the sample companies are revealed in the later descriptive analysis section. 
According to the financial reports released, the first disclosure of BIM usage in our sample companies was in 2010. Thus, the time frame from 2010 to 2018 is chosen as our study period. We used 'Building Information Modelling' or 'BIM' as key words to search the annual reports of our sample companies and found that 253 reports out of 109 companies claimed that their business operations involved BIM technology during 2010 and 2018. Therefore, a subsample of 253 panel observations of BIM adoption in different years was defined as BIM adopters (test group) in this study, and the rest not adopted observations are treated as the control group. After filtering of missing data, we finally achieved a sample size with 2,705 panel observations. The data for this study were collected through the databases of WIND and CSMAR. The statistical software used in this study was Stata 15.0.

\subsection{Variables definitions}

ROI is the most popular indicator adopted by previous studies to measure the project performance of BIM usage (Walasek and Barszcz 2017). However, from a corporation perspective, the ROI of BIM is hard to gain owing to corporation accounting policies. Walasek and Barszcz (2017) suggested that income, net revenue, and cash flow indicators are critical to decide whether BIM implementation is profitable. Therefore, return on assets (ROA) is chosen as the dependent variable to reflect the BIM performance in this study. Other common indicators of corporation profitability such as gross profit or net income ratio might have problems of collinearity with operation cost and administration expenses. The independent variable of BIM adoption in this study is designed as a dummy variable, in which 1 represents BIM-adopted and 0 represents notadopted.

According to the benefits of new technology and BIM implementation revealed by previous studies, this study has designed three mediation indicators to explore the influential mechanism effect of BIM adoption, namely, efficiency improvement, effectiveness enhancement, and cost reduction. We employ the business cycle to test whether BIM adoptions could bring about schedule efficiency improvement to company operations. Administration expense is used to examine the effect of cost reduction achieved by communication improvement as well as to represent the front-end investment of BIM technology. Cost of revenue is adopted to assess the cost reduction effect of BIM practice.

For control variables, as suggested by Barlish and Sullivan (2012) and Liu et al. (2017), we select indicators of corporation nature, age, ownership concentration, leverage, growth of sales, and fixed asset ratio to represent the possible influences of organization characteristics toward BIM success and corporation performance. This study further examines the BIM effect in different natures of enterprises, which are grouped as stateowned enterprises (SOEs) and non-state-owned enterprises (non-SOEs). The non-SOEs include private, public, and foreign controlled companies. Apart from company characteristics, the effects of year and industry are fixed since the sample is made up of panel observations. To avoid the impact of exceptional value on parameter estimation, $1 \%$ and $99 \%$ of winsorization are applied to the continuous variables. The variables of this study are displayed in Table 1.

\subsection{Methodology and models}

Multivariate regression analysis method is adopted to test the interrelationships and influential mechanisms between BIM adoption and corporate performance in this study. First, the total effect of BIM practice on the profitability performance of the AEC companies could be revealed by the coefficient and its significance of $\alpha_{1 i}$ in Model 1 (demonstrated in Eq. (1) and Figure 1) as follows:

$R O A_{i}=\alpha_{0 i}+\alpha_{i} B I M+\sum \alpha_{n i} C_{\text {Controls }}+\varepsilon \varepsilon_{i}$

Second, based on the methods of Baron and Kenny (1986), the impact of BIM adoption on effectiveness enhancement, efficiency improvement, and cost reduction could be revealed by the coefficient and its significance of $\beta_{1 i}$ in Model 2, as follows:

$$
\text { Mediators } i=\beta_{0 i}+\beta_{i i} B I M+\sum \beta_{m i} \text { Controls }_{i}+\varepsilon_{2 i}
$$

Finally, in Model 3 (shown in Eq. (3)), $\gamma_{1 i}$ represents the impact of BIM adoption on corporation profitability performance (also called direct effect) after controlling the effect of mediators and other control factors. The coefficient of $\gamma_{2 i}$, on the other hand, illustrates the impact of mediators on corporation profitability. The mediation effects of BIM adoption toward profitability through the mediators are equal to $\beta_{1 i}{ }^{\star} \gamma_{2 i}$, which could also be referred to as the indirect effect. The mediation models and effects are as follows (Figure 2):

$$
R O A_{i}=\gamma_{0 i}+\gamma_{1 i} B I M+\gamma_{2 i} \text { Medators }+\sum \gamma_{\text {mi Controls }}+\varepsilon_{3 i}
$$


Tab. 1: Variables list

\begin{tabular}{llll}
\hline Variables & Name & Code & Calculations \\
\hline Dependent variable & Profitability & ROA & Net income/Total assets \\
\hline Independent variable & BIM adoption & BIM & $\begin{array}{l}1=\text { adopted BIM } \\
0=\text { did not adopt BIM }\end{array}$ \\
\hline Mediation variables & Effectiveness & Admin & Administration expense/Revenue \\
& Efficiency & Cycle & Cost of revenue/Revenue \\
& Cost reduction & Cost & 1 = SOEs \\
& Nature of the enterprise & SOE & 0 Non-state-owned enterprise \\
& & & Ln (number of staff) \\
& Size & Size & Year-Foundation year \\
& Age & Age & The shares ratio of top 10 shareholders \\
& Ownership concentration & Top & Assets-liability ratio \\
& Leverage & Lev & Revenue $/$ Revenue \\
& Growth of sales & Growth & Fixed assets/total assets \\
& Tangible ratio & Tangible & Dummy variable of year \\
& Year & Year & Dummy variable of industry \\
& Industry & Industry &
\end{tabular}

BIM, building information modeling; ROA, return on assets; SOEs, state-owned enterprises.

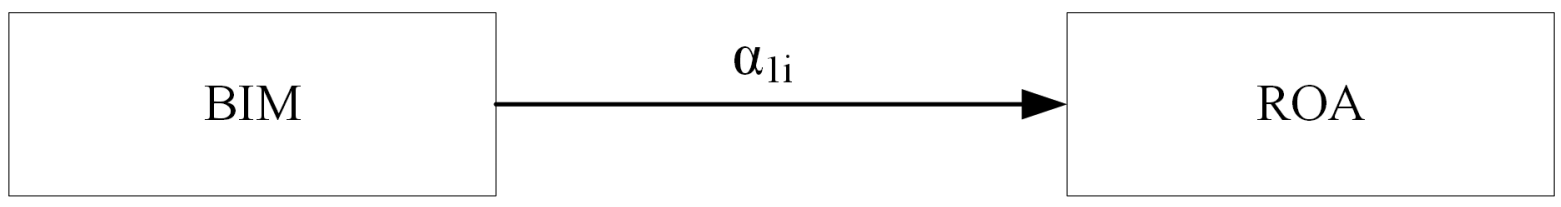

Fig. 1: The total effect of BIM adoption toward profitability. BIM, building information modeling.

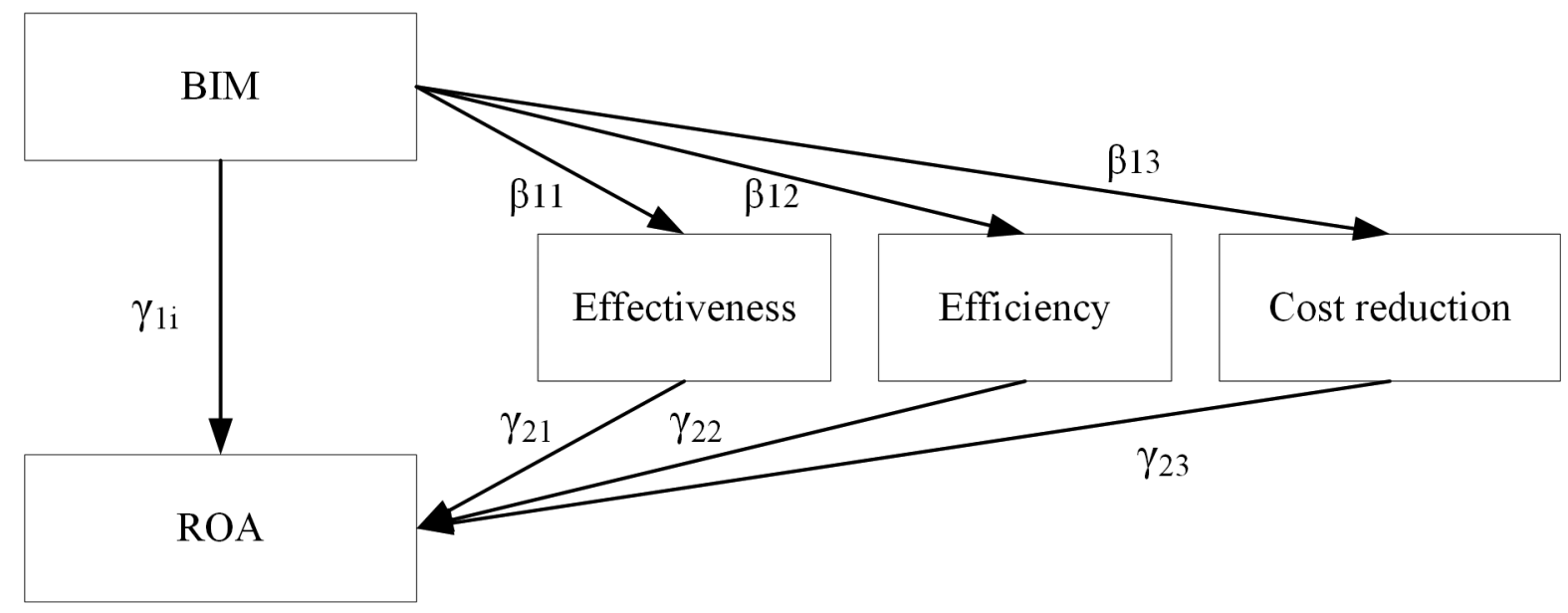

Fig. 2: The mediation models of BIM toward profitability. BIM, building information modeling.

\section{Empirical results}

\subsection{Descriptive analysis}

The changes in BIM adoption in China's listed AEC enterprises are shown in Figure 3. It can be seen that the BIM adoption rate in China before 2014 is $<5 \%$, with $<10$ companies reporting of BIM usage. Since the Chinese government officially established the BIM policy in 2015, the number of BIM adopted companies shows a steady trend of increase from 18 in 2014 to 74 by 2018 . The adoption rate rises from about $5.75 \%$ in 2014 to $23.57 \%$ by 2018 . Yet, it is worth to notice that the 


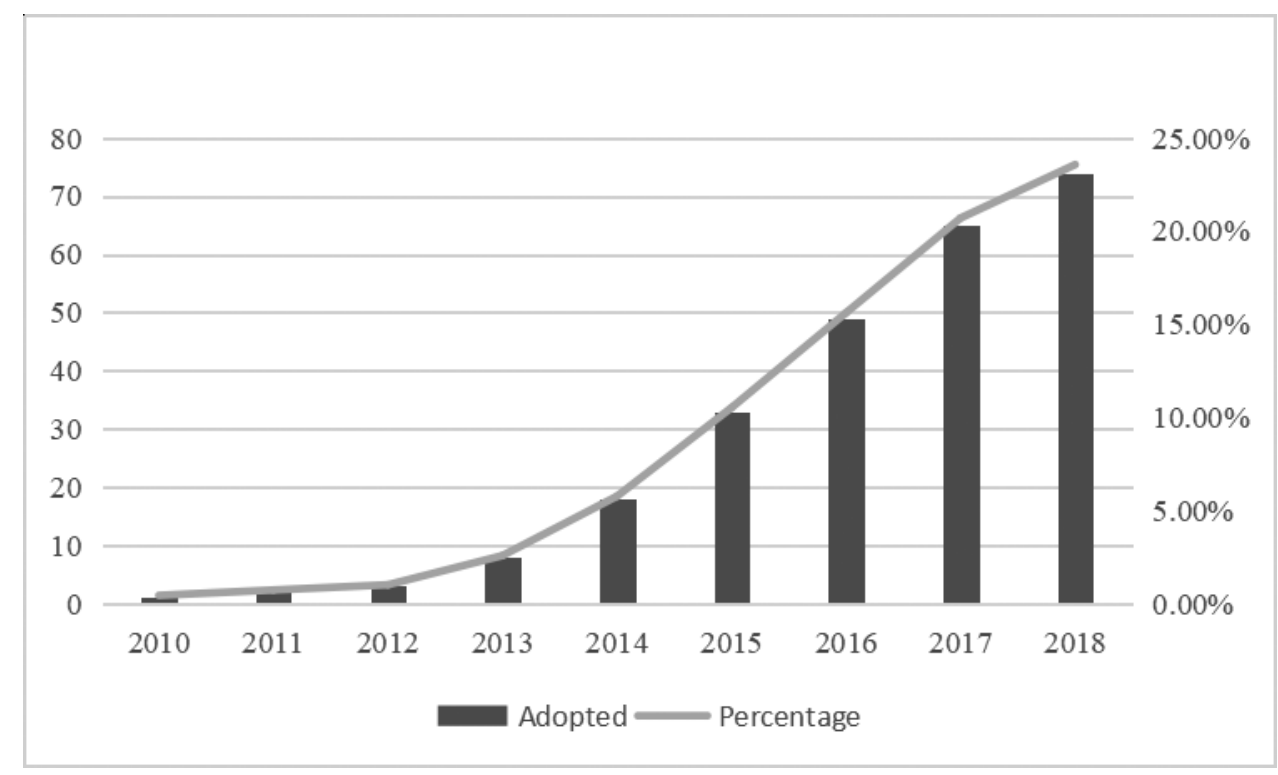

Fig. 3: The changes in BIM adoption among the listed AEC companies in China. AEC, architecture, engineering and construction; BIM, building information modeling.

Tab. 2: Results of descriptive analysis

\begin{tabular}{lcrrrr}
\hline Variables & Observation & Mean & $\begin{array}{c}\text { Standard } \\
\text { Deviation }\end{array}$ & Minimum & Maximum \\
& \multicolumn{5}{c}{} \\
\hline ROA & 2,705 & 6.918 & 15.731 & -5.923 & 28.094 \\
Cost & 2,705 & 69.382 & 15.731 & 25.247 & 95.596 \\
Cycle & 2,705 & 5.867 & 1.337 & 1.053 & 8.715 \\
Admin & 2,705 & 8.770 & 8.273 & 1.188 & 55.353 \\
Age & 2,704 & 17.438 & 5.928 & 0 & 35 \\
Top & 2,289 & 59.270 & 16.246 & 23.38 & 94.66 \\
Lev & 2,705 & 55.579 & 20.677 & 8.596 & 90.803 \\
Growth & 2,635 & 20.262 & 43.112 & -64.930 & 261.231 \\
Tangible & 2,705 & 9.915 & 14.294 & 0.063 & 73.782 \\
\hline
\end{tabular}

ROA, return on assets.

overall BIM adoption rate in China is still lower than the expectations.

Table 2 illustrates the descriptive features of the variables defined in the methodology section. It shows that the average financial performance (ROA) of the AEC companies in this study is about $6.90 \%$, with the lowest observation of $-5.90 \%$ and the highest record of $28.10 \%$. The mean operation cost ratio of the sample companies is up to $70 \%$ of their revenue, while the highest cost ratio reaches $>95 \%$. Companies of design departments or software supporting sectors have a lower cost ratio (lowest record of around $25.25 \%$ ), compared to that of the construction sector. The administration expense ratio of the sample companies, on the other hand, shows the lowest record of only $1.20 \%$ while the highest observation is $55.40 \%$. Yet, most of the companies have been devoted to controlling the administration expense and the average management expense ratio is around $8.80 \%$. These indicators imply that the AEC enterprises in China, especially those construction companies, might be suffering from increasing operation cost, which harms their financial performance and hinders their willingness for new technology investment. Owing to the diversity of business cycles among different industries, we calculate the natural logarithm of the original record and achieve a mean of about 5.9 in this study.

The characteristics of the control variables for the sample companies are also displayed in Table 2. It is shown that the average age of the enterprises is about 17 years, which is in line with the development of Chinese infrastructure and real-estate construction since 2000. The ownership concentration of the AEC companies in China is relatively high. On average, the top 10 shareholders own about $59 \%$ of the total shares and a maximum record of nearly $95 \%$. The leverage and fixed asset ratios show great discrepancies among the sample companies. It can be seen that the lowest record of leverage is only around $8.60 \%$, while the highest observation reaches $>90 \%$. In the meantime, the minimum fixed asset ratio is $0.06 \%$, while the highest is $73.80 \%$. The reasons underlying these discrepancies could be attributed to the heterogeneous operation requirements in different industries. For example, very few fixed assets are needed in architecture and design enterprises, while construction companies have to invest large capital in equipment for site work. The average growth of sales among the sample companies during $2010-2018$ is $20 \%$. However, some 
enterprises have a negative growth of sales, while others enjoy fast growth of $>260 \%$. These features indicate that there are significant diversities of business operations and financial performance among the listed AEC companies in China.

\subsection{Impacts of BIM adoption on financial performance}

The impacts of BIM practice on the financial performance (refer to Model 1 in Section 3.3) of AEC enterprises are shown in Table 3. Model (1) examines the relationship between BIM adoption and ROA in all samples, Models (2) and (3) are developed by subsamples divided according to the nature of the enterprises. The effects of control variables including year and industry are fixed in all models. It can be seen from Table 3 that all submodels are robust at the significant level of 0.001, with acceptable R-squares ranging from 0.246 to 0.282 .

Tab. 3: Impacts of BIM adoption on financial performance

\begin{tabular}{|c|c|c|c|}
\hline $\begin{array}{l}\text { Independent } \\
\text { variables }\end{array}$ & $\begin{array}{c}\text { Model (1) } \\
\text { All samples }\end{array}$ & $\begin{array}{l}\text { Model (2) } \\
\text { SOEs }\end{array}$ & $\begin{array}{l}\text { Model (3) } \\
\text { Non-SOEs }\end{array}$ \\
\hline BIM & $\begin{array}{l}0.916^{\star \star \star} \\
(3.334)\end{array}$ & $\begin{array}{c}0.185 \\
(0.475)\end{array}$ & $\begin{array}{l}1.342^{\star \star \star} \\
(3.473)\end{array}$ \\
\hline SOE & $\begin{array}{l}-0.653^{\star \star \star} \\
(-3.646)\end{array}$ & & \\
\hline Age & $\begin{array}{l}0.053^{\star \star \star *} \\
(3.057)\end{array}$ & $\begin{array}{l}0.083^{* \star *} \\
(3.721)\end{array}$ & $\begin{array}{c}0.008 \\
(0.292)\end{array}$ \\
\hline Size & $\begin{array}{l}0.270^{\star \star \star} \\
(4.327)\end{array}$ & $\begin{array}{l}0.262^{\star \star \star} \\
(3.616)\end{array}$ & $\begin{array}{l}0.614^{\star \star \star} \\
(5.362)\end{array}$ \\
\hline Top & $\begin{array}{l}0.058^{\star \star \star} \\
(11.083)\end{array}$ & $\begin{array}{l}0.038^{\star \star \star} \\
(5.428)\end{array}$ & $\begin{array}{l}0.075^{\star \star \star} \\
(9.752)\end{array}$ \\
\hline Lev & $\begin{array}{l}-0.061^{\star \star \star} \\
(-12.502)\end{array}$ & $\begin{array}{l}-0.064^{\star \star \star} \\
(-10.206)\end{array}$ & $\begin{array}{l}-0.064^{\star \star \star} \\
(-8.277)\end{array}$ \\
\hline Growth & $\begin{array}{l}0.016^{\star \star \star} \\
(9.321)\end{array}$ & $\begin{array}{l}0.009 * \star \star \\
(3.954)\end{array}$ & $\begin{array}{l}0.022^{\star \star \star} \\
(8.453)\end{array}$ \\
\hline Tangible & $\begin{array}{l}-0.024^{\star \star \star} \\
(-3.671)\end{array}$ & $\begin{array}{l}-0.008 \\
(-1.221)\end{array}$ & $\begin{array}{l}-0.056^{\star \star \star} \\
(-3.499)\end{array}$ \\
\hline _cons & $\begin{array}{l}3.696^{\star \star \star} \\
(5.554)\end{array}$ & $\begin{array}{l}4.162^{\star \star \star} \\
(5.005)\end{array}$ & $\begin{array}{c}1.125 \\
(1.027)\end{array}$ \\
\hline $\begin{array}{l}\text { Year } \\
\text { Industry }\end{array}$ & $\begin{array}{l}\text { Fixed } \\
\text { Fixed }\end{array}$ & $\begin{array}{l}\text { Fixed } \\
\text { Fixed }\end{array}$ & $\begin{array}{l}\text { Fixed } \\
\text { Fixed }\end{array}$ \\
\hline$N$ & 2,289 & 1,141 & 1,148 \\
\hline$R^{2}$ & 0.246 & 0.282 & 0.260 \\
\hline$p$-value & 0.000 & 0.000 & 0.000 \\
\hline
\end{tabular}

${ }^{\star \star \star} p<0.010,{ }^{\star \star} p<0.050,{ }^{\star} p<0.100$.

BIM, building information modeling; Non-SOEs, non-state-owned enterprises; SOEs, state-owned enterprises.
Overall, it can be seen from Model (1) in Table 3 that BIM adoption brings positive financial benefits to the AEC enterprises. The coefficient of BIM adoption toward ROA for all samples is 0.916 at the significance level of $1 \%$. However, the results of Model (2) reveal that there is no significant impact of BIM adoption on profitability in SOEs. As it is shown in Model (3), the BIM implementation leads to a significant increase of profitability in nonstate-owned AEC enterprises with a coefficient of 1.342 at the significant level of $1 \%$. For the control variables, the results in Table 3 illustrate that age, size, ownership concentration, and growth of sales have positive impacts on profitability, while leverage and tangible rate have negative effects toward ROA.

\subsection{Impact of BIM adoption on effectiveness}

First, the results in Table 4 illustrate the impacts of BIM adoption on administration expenses, which represents

Tab. 4: Impacts of BIM adoption on effectiveness

\begin{tabular}{|c|c|c|c|}
\hline $\begin{array}{l}\text { Independent } \\
\text { variables }\end{array}$ & $\begin{array}{c}\text { Model (4) } \\
\text { All samples }\end{array}$ & $\begin{array}{l}\text { Model (5) } \\
\text { SOEs }\end{array}$ & $\begin{array}{l}\text { Model (6) } \\
\text { Non-SOEs }\end{array}$ \\
\hline BIM & $\begin{array}{l}1.128^{\star \star} \\
(2.077)\end{array}$ & $\begin{array}{c}0.705 \\
(0.974)\end{array}$ & $\begin{array}{l}1.580^{\star \star} \\
(2.007)\end{array}$ \\
\hline SOE & $\begin{array}{l}-1.462^{\star \star \star} \\
(-4.127)\end{array}$ & & \\
\hline Age & $\begin{array}{l}-0.015 \\
(-0.435)\end{array}$ & $\begin{array}{l}-0.147^{\star \star \star} \\
(-3.525)\end{array}$ & $\begin{array}{l}0.144^{\star * \star} \\
(2.638)\end{array}$ \\
\hline Size & $\begin{array}{l}-0.533^{* \star *} \\
(-4.322)\end{array}$ & $\begin{array}{l}-0.428^{\star \star *} \\
(-3.181)\end{array}$ & $\begin{array}{l}-1.299 \text { *** } \\
(-5.570)\end{array}$ \\
\hline Top & $\begin{array}{l}-0.068^{\star \star \star} \\
(-6.592)\end{array}$ & $\begin{array}{l}-0.061^{\star \star *} \\
(-4.677)\end{array}$ & $\begin{array}{l}-0.078^{\star \star \star} \\
(-5.011)\end{array}$ \\
\hline Lev & $\begin{array}{c}-0.152^{\star \star \star} \\
(-15.659)\end{array}$ & $\begin{array}{l}-0.125^{\star \star \star} \\
(-10.723)\end{array}$ & $\begin{array}{l}-0.178^{\star \star \star} \\
(-11.315)\end{array}$ \\
\hline Growth & $\begin{array}{l}-0.027^{\star \star \star} \\
(-7.701)\end{array}$ & $\begin{array}{l}-0.024^{\star \star \star} \\
(-5.611)\end{array}$ & $\begin{array}{l}-0.028^{\star \star \star} \\
(-5.212)\end{array}$ \\
\hline Tangible & $\begin{array}{c}0.015 \\
(1.146)\end{array}$ & $\begin{array}{l}-0.024^{\star} \\
(-1.914)\end{array}$ & $\begin{array}{l}0.075^{\star \star} \\
(2.304)\end{array}$ \\
\hline _cons & $\begin{array}{l}26.310^{\star \star \star \star} \\
(20.005)\end{array}$ & $\begin{array}{l}24.715^{\star \star \star *} \\
(15.987)\end{array}$ & $\begin{array}{l}29.799 * * * \\
(13.356)\end{array}$ \\
\hline $\begin{array}{l}\text { Year } \\
\text { Industry }\end{array}$ & $\begin{array}{l}\text { Fixed } \\
\text { Fixed }\end{array}$ & $\begin{array}{l}\text { Fixed } \\
\text { Fixed }\end{array}$ & $\begin{array}{l}\text { Fixed } \\
\text { Fixed }\end{array}$ \\
\hline$N$ & 2,289 & 1,141 & 1,148 \\
\hline$R^{2}$ & 0.289 & 0.241 & 0.324 \\
\hline$p$-value & 0.000 & 0.000 & 0.000 \\
\hline
\end{tabular}

${ }^{\star \star \star} p<0.010,{ }^{\star \star} p<0.050,{ }^{\star} p<0.100$.

BIM, building information modeling; Non-SOEs, non-state-owned enterprises; SOEs, state-owned enterprises. 
the effectiveness of communication within the company and with external stakeholders, as well as the possible investment of BIM technology. The results of Model (4) in Table 4 prove that, for all enterprises, BIM adoption leads to significant higher administration expenses, with a coefficient of 1.128 at the significant level of 5\%. The phenomenon is similar to that of non-state-owned BIM adopters, as we could see the coefficient of BIM on administration expenses in Model (6) is 1.580 with a $p$-value of 0.050 . However, the impact of BIM adoption on management effectiveness for SOEs is insignificant, referring to the results in Model (5). In non-SOEs, age and tangible ratios are positively linked to administration expense ratios. Organizational characteristics including size, ownership concentration, leverage, and growth of sales, on the other hand, have negative impacts on administration expenses. The models in Table 4 are all robust at the significant level of 0.001 , with the adjusted R-square ranging from 0.241 to 0.324 , indicating that the variables have good explanations for administration expense differences.

\subsection{Impact of BIM adoption on efficiency}

The effects of BIM implementation on the efficiency improvement of business operation, represented by the indicator of business cycle, are shown in Table 5. The significantly negative coefficient of BIM in Model (7) (-0.133, significant at $10 \%$ ) illustrates that the implementation of BIM in Chinese AEC enterprises shortens their business cycle. However, these efficiency improvement effects only exist in the non-SOEs. The result in Model (9) shows that the coefficient of BIM for the non-SOEs is -0.261 at the significant level of $1 \%$. Their counterparts, however, fail to obtain efficiency improvement paybacks from BIM adoption, as the coefficient of BIM toward business cycle in SOEs is insignificant in Model (8). Other organizational characteristics, apart from leverage, also negatively influence the business cycle. The R-squares for Models (7) to (9) are higher, ranging from $46.60 \%$ to $62.40 \%$, indicating that the independent variable and control variables provide remarkable explanations to the business operation divergence.

\subsection{Impact of BIM adoption on cost reduction}

The influence of BIM adoption toward cost reduction in China's listed AEC enterprises is illustrated in Table 6. The results of Model (10) support the claim that BIM implementation lowers the construction or operation
Tab. 5: Impacts of BIM adoption on efficiency

\begin{tabular}{|c|c|c|c|}
\hline $\begin{array}{l}\text { Dependent } \\
\text { variables }\end{array}$ & $\begin{array}{c}\text { Model (7) } \\
\text { All samples }\end{array}$ & $\begin{array}{l}\text { Model (8) } \\
\text { SOEs }\end{array}$ & $\begin{array}{l}\text { Model (9) } \\
\text { Non-SOEs }\end{array}$ \\
\hline BIM & $\begin{array}{l}-0.133^{*} \\
(-1.890)\end{array}$ & $\begin{array}{c}0.072 \\
(0.596)\end{array}$ & $\begin{array}{l}-0.261^{\star \star \star} \\
(-3.330)\end{array}$ \\
\hline SOE & $\begin{array}{l}-0.092^{\star \star} \\
(-1.999)\end{array}$ & & \\
\hline Age & $\begin{array}{l}-0.020^{\star * \star} \\
(-4.534)\end{array}$ & $\begin{array}{l}-0.024^{\star \star \star} \\
(-3.429)\end{array}$ & $\begin{array}{l}-0.012^{\star \star} \\
(-2.219)\end{array}$ \\
\hline Size & $\begin{array}{l}-0.100^{\star \star \star} \\
(-6.267)\end{array}$ & $\begin{array}{l}-0.035 \\
(-1.560)\end{array}$ & $\begin{array}{l}-0.110^{\star \star \star} \\
(-4.735)\end{array}$ \\
\hline Top & $\begin{array}{l}-0.009^{\star * \star} \\
(-6.898)\end{array}$ & $\begin{array}{l}-0.011^{\star * \star} \\
(-5.006)\end{array}$ & $\begin{array}{l}-0.006^{\star \star \star} \\
(-3.666)\end{array}$ \\
\hline Lev & $\begin{array}{l}0.009^{\star \star *} \\
(6.970)\end{array}$ & $\begin{array}{l}0.005^{\star *} \\
(2.387)\end{array}$ & $\begin{array}{l}0.015^{\star \star *} \\
(9.374)\end{array}$ \\
\hline Growth & $\begin{array}{l}-0.002^{\star \star \star} \\
(-5.090)\end{array}$ & $\begin{array}{l}-0.002^{\star \star \star} \\
(-2.809)\end{array}$ & $\begin{array}{l}-0.003^{* \star \star} \\
(-4.704)\end{array}$ \\
\hline Tangible & $\begin{array}{c}-0.025^{\star \star \star} \\
(-14.720)\end{array}$ & $\begin{array}{l}-0.019 * \star \star \\
(-8.934)\end{array}$ & $\begin{array}{l}-0.034^{\star \star \star} \\
(-10.304)\end{array}$ \\
\hline _cons & $\begin{array}{c}8.089^{\star \star \star} \\
(47.438)\end{array}$ & $\begin{array}{l}8.081^{\star \star \star *} \\
(31.340)\end{array}$ & $\begin{array}{l}7.366^{\star \star \star} \\
(33.119)\end{array}$ \\
\hline $\begin{array}{l}\text { Year } \\
\text { Industry }\end{array}$ & $\begin{array}{l}\text { Fixed } \\
\text { Fixed }\end{array}$ & $\begin{array}{l}\text { Fixed } \\
\text { Fixed }\end{array}$ & $\begin{array}{l}\text { Fixed } \\
\text { Fixed }\end{array}$ \\
\hline$N$ & 2,289 & 1,141 & 1,148 \\
\hline$R^{2}$ & 0.539 & 0.624 & 0.466 \\
\hline$p$-value & 0.000 & 0.000 & 0.000 \\
\hline
\end{tabular}

${ }^{\star \star *} p<0.010,{ }^{\star *} p<0.050,{ }^{*} p<0.100$.

BIM, building information modeling; Non-SOEs, non-state-owned enterprises; SOEs, state-owned enterprises.

cost, as the coefficient of BIM on cost ratio is -3.49 at the significant level of 0.01 . The results of Model (12) indicate that private AEC enterprises have benefited from BIM technology in terms of cost savings. The coefficient of the BIM of non-SOEs in Model (12) is -3.870 and is significant at $1 \%$. However, this advantage is not shared by the SOEs, as revealed by the insignificant coefficient of BIM in Model (11). Besides, companies of smaller size, lower ownership concentration, higher leverage, and tangible rate also enjoy lower operation costs. The variables in Models (10)-(12) also have high R-squares, from $40.40 \%$ to $50.60 \%$.

\subsection{Mediation effects of BIM adoption toward profitability}

In this section, we test the mediation effects of BIM implementation toward financial performance through effectiveness enhancement, efficiency improvement, and cost reduction, referring to Models 2 and 3 in the methodology 
Tab. 6: Impacts of BIM adoption on cost reductions

\begin{tabular}{|c|c|c|c|}
\hline $\begin{array}{l}\text { Dependent } \\
\text { variables }\end{array}$ & $\begin{array}{l}\text { Model (10) } \\
\text { All samples }\end{array}$ & $\begin{array}{l}\text { Model (11) } \\
\text { SOEs }\end{array}$ & $\begin{array}{c}\text { Model (12) } \\
\text { Non-SOEs }\end{array}$ \\
\hline BIM & $\begin{array}{l}-3.490^{\star \star \star} \\
(-3.881)\end{array}$ & $\begin{array}{l}-2.104 \\
(-1.438)\end{array}$ & $\begin{array}{l}-3.870^{\star * \star} \\
(-3.444)\end{array}$ \\
\hline SOE & $\begin{array}{l}4.272^{\star \star \star} \\
(7.286)\end{array}$ & & \\
\hline Age & $\begin{array}{c}0.027 \\
(0.466)\end{array}$ & $\begin{array}{l}0.174^{\star *} \\
(2.069)\end{array}$ & $\begin{array}{l}-0.191^{\star *} \\
(-2.447)\end{array}$ \\
\hline Size & $\begin{array}{l}0.757^{\star \star \star} \\
(3.711)\end{array}$ & $\begin{array}{l}1.216^{\star \star \star} \\
(4.466)\end{array}$ & $\begin{array}{c}-0.241 \\
(-0.724)\end{array}$ \\
\hline Top & $\begin{array}{l}-0.074^{\star \star \star} \\
(-4.349)\end{array}$ & $\begin{array}{l}-0.084^{\star \star \star} \\
(-3.207)\end{array}$ & $\begin{array}{l}-0.087^{\star * \star} \\
(-3.887)\end{array}$ \\
\hline Lev & $\begin{array}{c}0.234^{\star \star \star} \\
(14.548)\end{array}$ & $\begin{array}{l}0.165^{\star \star \star} \\
(7.020)\end{array}$ & 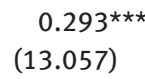 \\
\hline Growth & $\begin{array}{c}0.008 \\
(1.378)\end{array}$ & $\begin{array}{l}0.030^{\star \star \star *} \\
(3.575)\end{array}$ & $\begin{array}{l}-0.010 \\
(-1.307)\end{array}$ \\
\hline Tangible & $\begin{array}{l}0.077^{\star \star \star} \\
(3.552)\end{array}$ & $\begin{array}{l}0.070^{\star \star \star} \\
(2.748)\end{array}$ & $\begin{array}{c}0.053 \\
(1.143)\end{array}$ \\
\hline _cons & $\begin{array}{l}43.612^{\star \star \star} \\
(20.029)\end{array}$ & $\begin{array}{l}45.878^{\star * \star} \\
(14.666)\end{array}$ & $\begin{array}{l}53.382^{\star * \star} \\
(16.761)\end{array}$ \\
\hline $\begin{array}{l}\text { Year } \\
\text { Industry }\end{array}$ & $\begin{array}{l}\text { Fixed } \\
\text { Fixed }\end{array}$ & $\begin{array}{l}\text { Fixed } \\
\text { Fixed }\end{array}$ & $\begin{array}{l}\text { Fixed } \\
\text { Fixed }\end{array}$ \\
\hline$N$ & 2,289 & 1,141 & 1,148 \\
\hline$R^{2}$ & 0.443 & 0.506 & 0.404 \\
\hline$p$-value & 0.000 & 0.000 & 0.000 \\
\hline
\end{tabular}

${ }^{\star \star *} p<0.010,{ }^{\star \star} p<0.050,{ }^{\star} p<0.100$.

BIM, building information modeling; Non-SOEs, non-state-owned enterprises; SOEs, state-owned enterprises.

section. Owing to the insignificance relationships between BIM adoption and financial performance as well as the three mediators in SOEs (results in Tables 4-6), the analysis of mediation effects in this section only includes nonSOEs. The influences of BIM adoption and mediators on financial performance of the non-state-owned AEC enterprises are displayed in Table 7. As it is shown that the submodels of Model 3 are robust with a $p$-value of $<0.001$. The adjusted R-squares of the models are between 0.272 and 0.312 , indicating that the BIM implementation and mediation effects could properly explain the variety of corporate financial performance. It could be seen from the results in Table 7 that, the coefficients of BIM in Models (13)-(15) are $1.150,1.180$, and 0.990 , respectively, and significant at the level of $1 \%$. Combining with the results in Table 3, it demonstrates that BIM implementation in non-SOEs has a positive impact on corporate financial performance. Table 7 also shows that management expenses, business cycle, and operation cost are negatively related to corporation profitability with coefficients of $-0.106,-0.618$, and -0.091 at the significant level of $1 \%$.
Tab. 7: The influences of BIM adoption and mediators on financial performance

\begin{tabular}{|c|c|c|c|}
\hline $\begin{array}{l}\text { Dependent } \\
\text { variables }\end{array}$ & $\begin{array}{l}\text { Model (13) } \\
\text { All samples }\end{array}$ & $\begin{array}{l}\text { Model (14) } \\
\text { SOEs }\end{array}$ & $\begin{array}{c}\text { Model (15) } \\
\text { Non-SOEs }\end{array}$ \\
\hline BIM & $\begin{array}{l}1.510^{\star \star \star} \\
(3.995)\end{array}$ & $\begin{array}{l}1.180^{\star \star \star *} \\
(3.063)\end{array}$ & $\begin{array}{l}0.990^{\star \star \star} \\
(2.643)\end{array}$ \\
\hline Admin & $\begin{array}{l}-0.106^{\star \star \star} \\
(-7.456)\end{array}$ & & \\
\hline Cycle & & $\begin{array}{l}-0.618^{\star \star \star} \\
(-4.242)\end{array}$ & \\
\hline Cost & & & $\begin{array}{l}-0.091^{\star \star \star} \\
(-9.187)\end{array}$ \\
\hline Age & $\begin{array}{c}0.023 \\
(0.883)\end{array}$ & $\begin{array}{c}0.000 \\
(0.014)\end{array}$ & $\begin{array}{l}-0.009 \\
(-0.366)\end{array}$ \\
\hline Size & $\begin{array}{l}0.475^{\star \star \star} \\
(4.196)\end{array}$ & $\begin{array}{l}0.546^{\star \star \star} \\
(4.757)\end{array}$ & $\begin{array}{l}0.592^{\star \star \star} \\
(5.358)\end{array}$ \\
\hline Top & $\begin{array}{l}0.067^{\star * \star} \\
(8.774)\end{array}$ & $\begin{array}{l}0.071^{\star \star \star} \\
(9.306)\end{array}$ & $\begin{array}{l}0.067^{\star \star \star} \\
(8.982)\end{array}$ \\
\hline Lev & $\begin{array}{l}-0.083^{\star * \star} \\
(-10.414)\end{array}$ & $\begin{array}{l}-0.055^{\star \star \star} \\
(-6.890)\end{array}$ & $\begin{array}{l}-0.037^{\star \star \star} \\
(-4.663)\end{array}$ \\
\hline Growth & $\begin{array}{l}0.019 \star \star \star \star \\
(7.409)\end{array}$ & 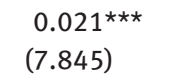 & $\begin{array}{l}0.022^{\star \star \star} \\
(8.397)\end{array}$ \\
\hline Tangible & $\begin{array}{l}-0.048^{\star \star \star} \\
(-3.064)\end{array}$ & $\begin{array}{l}-0.077^{\star \star \star} \\
(-4.615)\end{array}$ & $\begin{array}{l}-0.051^{\star \star \star} \\
(-3.311)\end{array}$ \\
\hline _cons & $\begin{array}{l}4.298^{\star \star \star \star} \\
(3.735)\end{array}$ & $\begin{array}{l}5.675^{\star \star \star} \\
(3.716)\end{array}$ & $\begin{array}{l}5.973^{\star \star \star} \\
(5.058)\end{array}$ \\
\hline $\begin{array}{l}\text { Year } \\
\text { Industry }\end{array}$ & $\begin{array}{l}\text { Fixed } \\
\text { Fixed }\end{array}$ & $\begin{array}{l}\text { Fixed } \\
\text { Fixed }\end{array}$ & $\begin{array}{l}\text { Fixed } \\
\text { Fixed }\end{array}$ \\
\hline$N$ & 1,148 & 1,148 & 1,148 \\
\hline$R^{2}$ & 0.295 & 0.272 & 0.312 \\
\hline$p$-value & 0.000 & 0.000 & 0.000 \\
\hline
\end{tabular}

BIM, building information modeling; Non-SOEs, non-state-owned enterprises.

Together with the results of Models 2 and 3 from Table 5 to Table 7, the mediation effects of BIM implementation through effectiveness enhancement, efficiency improvement, and cost reduction toward corporation performance in SOEs are shown in Figure 4. First, it demonstrates that BIM technology increases management expenses, shortens business operation cycle, and reduces operation cost in the BIM implementation companies. Second, lower management expenses, shorter business cycles, and lower operation costs lead to better financial profitability of the BIM-adopted AEC companies in China.

Finally, by multiplying the coefficients of BIM adoption toward the three mediators with the coefficients of the mediators toward ROA, the mediation effects could be summarized as follows: (1) BIM implementation in China's AEC enterprises increases their administration expenses and thus leads to a negative mediation effect toward 


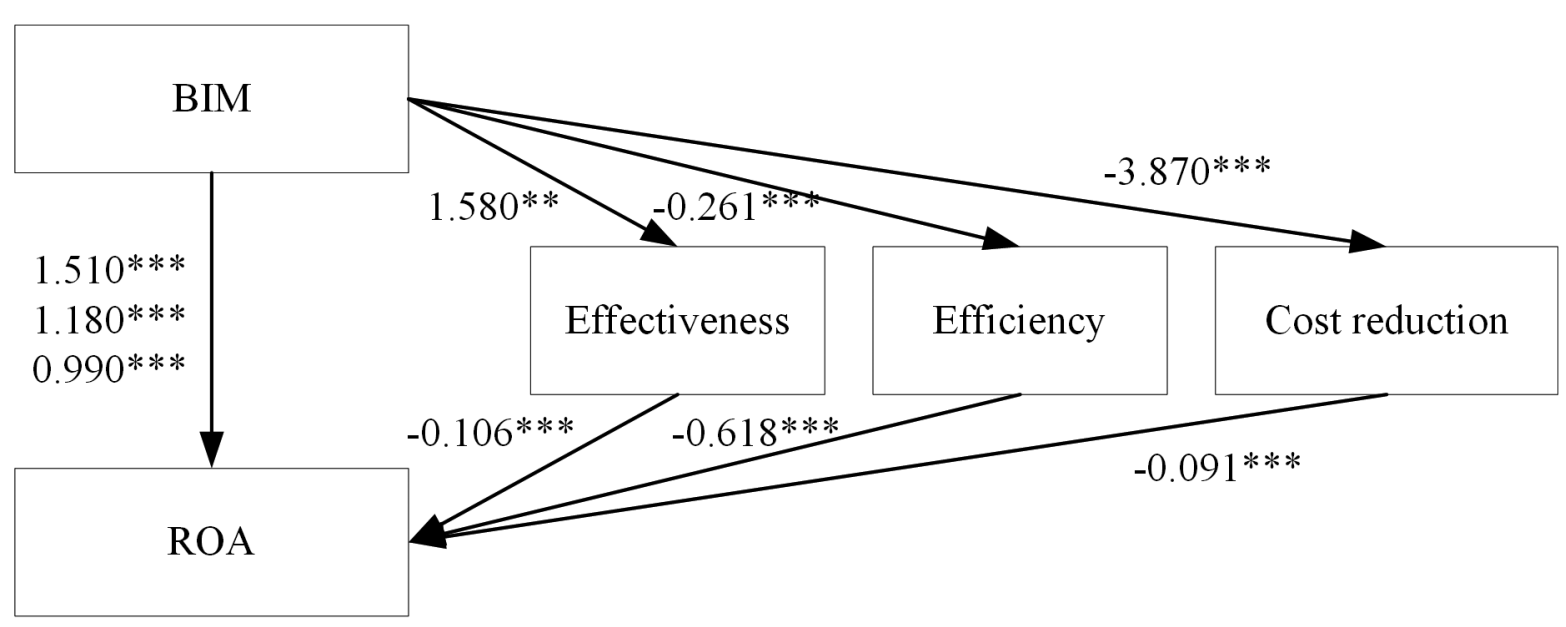

Fig. 4: Mediation effect of BIM implementation in non-SOEs. BIM, building information modeling; Non-SOEs, non-state-owned enterprises; SOEs, state-owned enterprises.

profitability performance; (2) the efficiency improvement brought about by BIM implementation in AEC enterprises shortens their business cycle, which achieves better performance in profitability; (3) BIM adoption generates benefits of operation cost savings, which further has a positive impact on the profitability in the non-SOE AEC enterprises.

\section{Discussion}

The empirical results of this study reveal that BIM implementation brings about better profitability performance in Chinese listed AEC enterprises. However, this effect is found in non-SOEs only. The positive link between BIM and profitability performance is attributed to the BIMassociated benefits of efficiency improvement and cost reduction. However, the well-recognized benefit of efficiency enhancement in the management of BIM technology is not supported by the results of this study. The possible reasons for these results are discussed below.

First, it is interesting to find that BIM benefits such as better profitability, efficiency improvement, and cost reduction only appear in non-SOEs of China. The stateowned AEC enterprises, however, fail to transform BIM advantages into corporation performance benefits. The possible reasons for this phenomenon might link to the fact that BIM implementation in China is in its early stages and is promoted by the Chinese government (Mohurd 2015). Thus, BIM usage in SOEs of the AEC industries might be carried out as an administrative task given by the government policies rather than as an innovation and reengineering of the operation processes (Xin et al. 2019). In addition, BIM implementation requires accompanying changes to the work practice and business process (Lindblad and Vass 2015). Criticized for resistance to change, the SOEs find it hard to achieve the benefit of BIM with inadequate organizational support (Tan et al. 2019, Liu et al. 2017). The adoption of BIM by non-SOEs, on the other hand, is more likely to be a strategic choice, as they have less pressure of administrative duties to undertake. Driven by strategical motivation, non-SOEs might have greater support and better collaboration at organizational levels for BIM implementation, which strengthens BIM benefits (Son et al. 2015).

Second, this study proves that BIM implementation brings about the benefits of financial performance to the AEC enterprises in China through the mediation effects of efficiency improvement by shortening business operation duration and reducing operation cost. However, these BIM-adopted companies also experience an increase in administration expenses, compared to their counterparts. One explanation is that, most of the applications of BIM tools in China are in model design, construction simulation, construction management, and visualization (Li et al. 2018). These applications are advanced in reducing unnecessary waste from rework and re-planning to achieve better schedule, project efficiency, and investment savings (Li et al. 2018). However, BIM application in China is still in the inception phase, which requires high initial investment for BIM hardware and software procuring (Tan et al. 2019) as well as professional staff training (Oteng et al. 2018). This BIM investment would inevitably increase the administration expenses of the AEC enterprises. Yet, implementing innovative technologies in the AEC industries is a lengthy process (Chan et al. 2019). In a longer-term perspective, BIM will achieve cost reduction and cost control through the project life cycle 
(Bryde et al. 2013). Another possible explanation is that the effectiveness enhancement benefits of BIM implementation mostly appear at the project level, such as less staff turnover and fewer contractual claims (Ghaffarianhoseini et al. 2017). The benefits of improving corporation management are difficult to achieve unless the effort of process reengineering practice is made at the organizational level (Lindblad and Vass 2015).

\section{Conclusion}

This study examines the impacts of BIM implementation on corporation performance, using data from Chinese listed AEC enterprises. The findings provide clear empirical evidence that: (1) BIM practice brings about the benefits of efficiency improvement and cost reduction, which further promotes financial performance in AEC enterprises in China; (2) high initial investment of BIM technology is required at this stage and the corporation managerial effectiveness enhancement benefits claimed by BIM have not been achieved; and (3) the benefits of BIM adoption in China are obtained by non-SOEs only, possibly owing to the divergence of willingness and width of adoption in different types of enterprises. This study suggests that, with advantages in government leading and policy support, Chinese AEC enterprises should make full use of the BIM capacity to gain greater effects. Although BIM investment would lead to short-term increase in expense, it should not offset the longer benefits of BIM practice.

However, due to the problem of data availability, this paper could not include the unlisted AEC companies into the analysis. And the impact of the depth and width of BIM implementation is unable to be examined in the sample enterprises. Future studies could further test the benefits of BIM adoption by developing more detailed measurements and investigations.

\section{Data Availability}

Some or all data, models, or code generated or used during the study are available from the corresponding author by request.

\section{Acknowledgement}

This work was supported by the National Social Science Fund of China (Youth Project) (No. 17CSH028).

\section{Notation list}

The following symbols are used in this paper:

$\mathrm{AEC}=$ Architecture, engineering and construction

$\mathrm{BIM}=$ Building information modeling

IT = Internet technology

SOE $=$ State-owned-enterprises

\section{References}

Aladag, H., Demirdögen, G., \& ISIK, Z. (2016). Building information modeling (BIM) use in Turkish construction industry. Procedia Engineering, 161, pp. 174-179.

Albadvi, A., Keramati, A., \& Razmi, J. (2007). Assessing the impact of information technology on firm performance considering the role of intervening variables: Organizational infrastructures and business processes reengineering. International Journal of Production Research, 45, pp. 2697-2734.

Azhar, S., Khalfan, M. M. A., \& Maqsood, T. (2012). Building information modelling (BIM): Now and beyond. Australasian Journal of Construction Economics and Building, 12, pp. 15-28.

Barlish, K., \& Sullivan, K. (2012). How to measure the benefits of BIM - A case study approach. Automation in Construction, 24, pp. 149-159.

Baron, R. M., \& Kenny, D. A. (1986). The moderator-mediator variable distinction in social psychological research: Conceptual, strategic, and statistical considerations. Journal of Personality and Social Psychology, 51, pp. 1173-1182.

Bryde, D., Broquetas, M., \& Volm, J. M. (2013). The project benefits of Building Information Modelling (BIM). International Journal of Project Management, 31, pp. 971-980.

Bui, N., Merschbrock, C., \& Munkvold, B.E. (2016). A review of building information modelling for construction in developing countries. Procedia Engineering, 164, pp. 487-494.

Cao, D., Wang, G., Li, H., Skitmore, M., Huang, T., \& Zhang, W. (2015). Practices and effectiveness of building information modelling in construction projects in China. Automation in Construction, 49, pp. 113-122.

Chan, D. W. M., Olawumi, T. O., \& Ho, A. M. L. (2019). Perceived benefits of and barriers to Building Information Modelling (BIM) implementation in construction: The case of Hong Kong. Journal of Building Engineering, 25, p. 100764.

Cheng, J. C., \& Lu, Q. (2015). A review of the efforts and roles of the public sector for BIM adoption worldwide. Journal of Information Technology in Construction (ITcon), 20, pp. $442-478$.

Chien, K.-F., Wu, Z.-H., \& Huang, S.-C. (2014). Identifying and assessing critical risk factors for BIM projects: Empirical study. Automation in Construction, 45, pp. 1-15.

Cline, M. K., \& Guynes, C. S. (2001). A study of the impact of information technology investment on firm performance. Journal of Computer Information Systems, 41, pp. 15-19.

Doms, M. E., Jarmin, R. S., \& Klimek, S. D. (2004). Information technology investment and firm performance in Us retail trade. Economics of Innovation and New Technology, 13, pp. 595-613.

Doumbouya, L., Gao, G., \& Guan, C. (2016). Adoption of the building information modeling (BIM) for construction project 
effectiveness: The review of BIM benefits. American Journal of Civil Engineering and Architecture, 4, pp. 74-79.

Georgiadou Maria, C. (2019). An overview of benefits and challenges of building information modelling (BIM) adoption in UK residential projects. Construction Innovation, 19, pp. 298-320.

Ghaffarianhoseini, A., Tookey, J., Ghaffarianhoseini, A., Naismith, N., Azhar, S., Efimova, O., et al. (2017). Building information modelling (BIM) uptake: Clear benefits, understanding its implementation, risks and challenges. Renewable and Sustainable Energy Reviews, 75, pp. 1046-1053.

Gledson Barry, J., \& Greenwood, D. (2017). The adoption of 4D BIM in the UK construction industry: An innovation diffusion approach. Engineering, Construction and Architectural Management, 24, pp. 950-967.

Hellegers, P., Zeng, D., \& Zilberman, D. (2011). Technology adoption and the impact on average productivity. Economics of Innovation and New Technology, 20, pp. 659-680.

Herr, C. M., \& Fischer, T. (2019). BIM adoption across the Chinese AEC industries: An extended BIM adoption model. Journal of Computational Design and Engineering, 6, pp. 173-178.

Hong, Y., Hammad Ahmed, W. A., Sepasgozar, S., \& Akbarnezhad, A. (2019). BIM adoption model for small and medium construction organisations in Australia. Engineering, Construction and Architectural Management, 26, pp. 154-183.

Jin, R., Hancock Craig, M., Tang, L., \& Wanatowski, D. (2017). BIM investment, returns, and risks in China's AEC industries. Journal of Construction Engineering and Management, 143, p. 04017089.

Jones, S. A., \& Bernstein, H. M. (2012). The Business Value of BIM in North America Multi Year Trend Analysis and User Ratings (2007-2012), McGraw-Hill Construction, Bedford.

Khoshfetrat, R., Sarvari, H., Chan, D. W. M., \& Rakhshanifar, M. (2020). Critical risk factors for implementing building information modelling (BIM): A Delphi-based survey. International Journal of Construction Management, pp. 1-10. DOI: $10.1080 / 15623599.2020 .1788759$

Kim, J., Kim, S., \& Lee, H. (2011). An effect of technology innovation activity on firm value and a mediation effect of leverage: Evidence from Korean firms. Asian Journal of Technology Innovation, 19, pp. 37-51.

Li, J., Li, N., Peng, J., Cui, H., \& Wu, Z. (2018). A review of currently applied building information modeling tools of constructions in China. Journal of Cleaner Production, 201, pp. 358-368.

Lin, Y.-C., \& Yang, H.-H. (2018). A framework for collaboration management of BIM model creation in architectural projects. Journal of Asian Architecture and Building Engineering, 17, pp. 39-46.

Lindblad, H., \& Vass, S. (2015). BIM implementation and organisational change: A case study of a large Swedish public client Procedia Economics and Finance, 21, pp. 178-184.

Lindblad, H. (2013). Study of the Implementation Process of BIM in Construction Projects: Analysis of the Barriers Limiting BIM Adoption in the AEC-Industry. Master, KTH Stockholm.

Liu, X., \& Wu, X. (2011). Technology embeddedness, innovation differentiation strategies and firm performance: Evidence from Chinese manufacturing firms. Innovation, 13, pp. 20-35.

Liu, Y., Van Nederveen, S., \& Hertogh, M. (2017). Understanding effects of BIM on collaborative design and construction:
An empirical study in China. International Journal of Project

Management, 35, pp. 686-698.

Love, P. E. D., Simpson, I., Hill, A., \& Standing, C. (2013). From justification to evaluation: Building information modeling for asset owners. Automation in Construction, 35, pp. 208-216.

Lu, Q., Won, J., \& Cheng, J. C. P. (2016). A financial decision making framework for construction projects based on 5D Building information modeling (BIM). International Journal of Project Management, 34, pp. 3-21.

Mehran, D. (2016). Exploring the adoption of BIM in the UAE construction industry for AEC firms. Procedia Engineering, 145, pp. 1110-1118.

Mohurd (2015). Guideline on the Application of Building Information Modelling Guiding Opinions on Promoting Building Information Models, Notice No. 159. In: Mohurd (ed.). Beijing: Ministry of Housing and Urban-Rural Development of the People's Republic of China (MOHURD), 1-11.

Olawumi, T. O., \& Chan, D. W. M. (2019). An empirical survey of the perceived benefits of executing BIM and sustainability practices in the built environment. Construction Innovation, 19, pp. 321-342.

Oteng, D., Ansah, M., Kissi, E., \& Eshun, B. (2018). Barriers to the adoption of Building Information Modelling in Developing Countries: The Case of Ghana. 1st International Conference on Construction Futures.

Rehman, N., Razaq, S., Farooq, A., Zohaib, N. M., \& Nazri, M. (2020). Information technology and firm performance: mediation role of absorptive capacity and corporate entrepreneurship in manufacturing SMEs. Technology Analysis \& Strategic Management, 32, pp. 1049-1065.

Singh, V., \& Holmström, J. (2015). Needs and technology adoption: Observation from BIM experience. Engineering, Construction and Architectural Management, 22, pp. 128-150.

Son, H., Lee, S., \& Kim, C. (2015). What drives the adoption of building information modeling in design organizations? An empirical investigation of the antecedents affecting architects' behavioral intentions. Automation in Construction, 49, pp. 92-99.

Tan, T., Chen, K., Xue, F., \& Lu, W. (2019). Barriers to building information modeling (BIM) implementation in China's prefabricated construction: An interpretive structural modeling (ISM) approach. Journal of Cleaner Production, 219, pp. 949-959.

Thatcher, M. E., \& Oliver, J. R. (2001). The impact of technology investments on a firm's production efficiency, product quality, and productivity. Journal of Management Information Systems, 18, pp. 17-45.

Walasek, D., \& Barszcz, A. (2017). Analysis of the adoption rate of building information modeling [BIM] and its return on investment [ROI]. Procedia Engineering, 172, pp. 1227-1234.

Won, J., \& Lee, G. (2016). How to tell if a BIM project is successful: A goal-driven approach. Automation in Construction, 69, pp. 34-43.

Xin, Q., Bao, A., \& Hu, F. (2019). West meets east: Understanding managerial incentives in Chinese SOEs. China Journal of Accounting Research, 12, pp. 177-189.

Zhou, Y., Yang, Y., \& Yang, J.-B. (2019). Barriers to BIM implementation strategies in China. Engineering, Construction and Architectural Management, 26, pp. 554-574. 